\title{
Single amplification PCR targeting mitochondrial genome more sensitive in diagnosing malaria than nested 18S PCR among returned travelers in Bergen, Norway
}

\author{
Christel Gill Haanshuus ${ }^{1 *}$, Stein Christian Mohn ${ }^{1}$, Kristine Mørch ${ }^{1}$, Nina Langeland ${ }^{2}$, Bjørn Blomberg ${ }^{1,2}$, \\ Kurt Hanevik ${ }^{1,2}$
}

From Challenges in malaria research

Basel, Switzerland. 10-12 October 2012

\section{Background}

Nested PCR is a commonly used molecular technique diagnosing malaria because of its high sensitivity and specificity. However, it is time consuming, has low costefficiency and considerable risk of contamination. Using amplification targets presented in multiple copies, such as rRNA $18 \mathrm{~S}$ locus, increases sensitivity. Mitochondrial targets with a higher copy number might further increase sensitivity.

\section{Methods}

The sensitivity and specificity of two newly designed Plasmodium genus-specific single amplification PCR programs, based on previously published primers targeting the $18 \mathrm{~S}$ locus [1] and the mitochondrial genome [2], were compared with a widely used nested 18S PCR [3]. Analyses in dilution series made from standardised $P$. falciparum reference material were performed, as well as retrospective analyses in 135 blood samples, previously evaluated by routine microscopy, from a cohort of 132 fever patients with potential imported malaria. In addition, sequencing of the $220 \mathrm{bp}$ mitochondrial PCR products was performed.

\section{Results}

The new single mitochondrial PCR detected dilutions down to 0.5 parasites/ $\mu$ l with $97 \%$ sensitivity (29/30 parallels), while the single $18 \mathrm{~S}$ PCR and nested $18 \mathrm{~S}$ PCR

${ }^{1}$ National Centre for Tropical Infectious Diseases, Department of Medicine, Haukeland University hospital, Bergen, Norway

Full list of author information is available at the end of the article detected $0.5 \mathrm{p} / \mu \mathrm{l}$ with $93 \%$ and $87 \%$ sensitivity, respectively. All three assays detected positive DNA as low as $0.05 \mathrm{p} / \mu \mathrm{l}$, though not consistently so by any method. Among the patient samples, 20.7 \% (28/135) were evaluated as malaria positive by microscopy and PCR combined. Both single amplification PCR assays identified malaria genus with $100 \%$ accuracy compared to 27 positives detected by the nested 18S PCR reference method. The mitochondrial PCR detected one more positive than the $18 \mathrm{~S}$ PCR assays, which was also positive by microscopy, and had $100 \%$ sensitivity (28/28). Routine microscopy missed two infections detected by all three PCR assays. Sequencing of the genus-specific mitochondrial PCR products revealed different single nucleotide polymorphisms which allowed a species-specific identification of the 28 sequences with following distribution of species; 20 P. falciparum, six $P$. vivax, one $P$. ovale and one $P$. malariae.

\section{Conclusions}

Design of PCR programs with suitable parameters and optimization resulted in simpler and faster single amplification assays without reducing the sensitivity and specificity compared to a nested PCR reference method. The new mitochondrial PCR, where the amplification target has a higher copy number than for $18 \mathrm{~S}$ targets, had in this study highest sensitivity, both among standardised reference and patient material, compared to the $18 \mathrm{~S}$ PCR assays. Sequencing of genus-specific mitochondrial PCR products might be useful as a species determination method, and merits further investigation. 


\section{Author details}

${ }^{1}$ National Centre for Tropical Infectious Diseases, Department of Medicine,

Haukeland University hospital, Bergen, Norway. ${ }^{2}$ Institute of Medicine,

University of Bergen, Norway.

Published: 15 October 2012

\section{References}

1. Snounou G, Viriyakosol S, Zhu XP, Jarra W, Pinheiro L, do Rosario VE,

Thaithong S, Brown KN: High sensitivity of detection of human malaria parasites by the use of nested polymerase chain reaction. Molecular and biochemical parasitology 1993, 61:315-320.

2. Polley SD, Mori Y, Watson J, Perkins MD, Gonzalez IJ, Notomi T, Chiodini PL, Sutherland $\mathrm{CJ}$ : Mitochondrial DNA targets increase sensitivity of malaria detection using loop-mediated isothermal amplification. Journal of clinical microbiology 2010, 48:2866-2871.

3. Singh B, Bobogare A, Cox-Singh J, Snounou G, Abdullah MS, Rahman HA: A genus- and species-specific nested polymerase chain reaction malaria detection assay for epidemiologic studies. The American journal of tropical medicine and hygiene 1999, 60:687-692.

doi:10.1186/1475-2875-11-S1-P116

Cite this article as: Haanshuus et al:: Single amplification PCR targeting mitochondrial genome more sensitive in diagnosing malaria than nested 18S PCR among returned travelers in Bergen, Norway. Malaria Journal 2012 11(Suppl 1):P116.

\section{Submit your next manuscript to BioMed Central and take full advantage of:}

- Convenient online submission

- Thorough peer review

- No space constraints or color figure charges

- Immediate publication on acceptance

- Inclusion in PubMed, CAS, Scopus and Google Scholar

- Research which is freely available for redistribution

Submit your manuscript at www.biomedcentral.com/submit 